\title{
Guanine nucleotides reduce the free calcium requirement for secretion of granule constituents from permeabilized human neutrophils
}

\author{
James E. Smolen and Sally J. Stoehr \\ Division of Pediatric Hematology - Oncology. University of Michigan Medical School, Ann Arbor, MI 48109 (U.S.A.)
}

(Received 18 February 1986)

(Revised manuscript received 4 August 1986)

Key words: $\mathrm{Ca}^{2+}$ requirement; Guanine nucleotide: Granule constituent secretion; G-protein; (Human neutrophil)

Human neutrophils can be permeabilized with the cholesterol complexing agent digitonin and then induced to secrete lysosomal constituents by increases in free $\mathrm{Ca}^{2+}$ alone. In order of increasing requirements for $\mathrm{Ca}^{2+}$, vitamin B-12 binding protein, lysozyme and $\beta$-glucuronidase were released. $\mathrm{A}$ variety of guanine nucleotides were examined with respect to their abilities to modulate this response. GTP, along with its

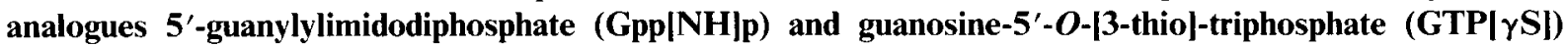
decreased the $\mathrm{Ca}^{2+}$ requirements for secretion of all three granule constituents by one third to one order of magnitude. This synergy was dependent upon the concentration of guanine nucleotides employed. The effects of Gpp[NH]p could be blocked with the inactive derivative GDP[ $\beta$-S]. The active guanine nucleotides, particularly GTP, served as stimuli in their own right. At high concentrations of $\mathrm{Ca}^{2+}$ and GTP, degranulation was strikingly inhibited; inhibition was also achieved with high concentrations of guanylyl $\beta, \gamma$-methylene]diphosphate $\left(\mathrm{Gpp}\left|\mathrm{CH}_{2}\right| \mathrm{p}\right)$. Both GDP and GMP were without any effect. When neutrophils were pretreated with pertussis toxin, granule discharge induced by fMet-Leu-Phe was almost completely blocked, as reported by others. If the neutrophils pretreated with pertussis toxin were then permeabilized with digitonin, the synergy between $\mathrm{Ca}^{2+}$ and the stimulatory guanine nucleotides was maintained. These data suggest the involvement of G-proteins in secretion induced by $\mathrm{Ca}^{2+}$; however, this response either uses a different G-protein or a different pool of G-proteins from those responses triggered by $\mathbf{f M e t}-$ Leu-Phe.

\section{Introduction}

Intracellular free $\mathrm{Ca}^{2+}$ has been strongly implicated as a second messenger in stimulus-response coupling in neutrophils. Responses to surface stimuli can be inhibited by extracellular chelators [1] and calcium channel blockers [2] and can be entirely eliminated by intracellular $\mathrm{Ca}^{2+}$ antagonists [1]. Intracellular $\mathrm{Ca}^{2+}$ mobilization appears to be very rapid, as measured by either a

Correspondence: Dr. J.E. Smolen, Division of Pediatric Hematology-Oncology, University of Michigan Medical School, Ann Arbor, MI 48109, U.S.A. decrease in putative membrane-bound $\mathrm{Ca}^{2+}$ with chlortetracyclin [3-6] or an increase in cytosolic free $\mathrm{Ca}^{2+}$ as monitored with the chelating probe quin2 [7-11]. This increase in cytosolic free $\mathrm{Ca}^{2+}$ appears to be a prerequisite for secretion in response to most surface stimuli [8-11].

Other recent results implicate G-proteins in the stimulus-response coupling pathway. In particular, neutrophil responses to fMet-Leu-Phe, a stimulus which interacts with defined receptors on the cell surface, are blocked by pretreatment of the cells with pertussis toxin. Pertussis toxin covalently modifies the inhibitory G-protein, $\mathrm{N}_{\mathrm{i}}$. Virtually all of the neutrophil responses to fMet-Leu-Phe, such 
as elevation in intracellular $\mathrm{Ca}^{2+}$ [12], superoxide anion generation [13], lysosomal enzyme release [13-15], aggregation [13], chemotaxis [13,15], fMet-Leu-Phe binding [13], cytoskeletal changes [16], phosphatidylinositol turnover [14,17] and protein phosphorylation [17] are blocked by this toxin. Stimuli which directly activate protein kinase $C$, such as $4 \beta$-phorbol 12-myristate 13acetate, are not affected by pertussis toxin [15-17]. Furthermore, guanine nucleotides can regulate the affinity of the fMet-Leu-Phe receptor [18].

We have recently reported that $\mathrm{Ca}^{2+}$ alone serves to elicit granule discharge from neutrophils permeabilized with the cholesterol-complexing agents saponin or digitonin $[19,20]$. No apparent cofactors were required for this response. However, $\mathrm{Ca}^{2+}$ requirements for secretion in this system were $10-30$-fold higher than that reported to be present in stimulated neutrophils as monitored by quin2 [7-11]. We now report that guanine nucleotides act synergistically with $\mathrm{Ca}^{2+}$, significantly reducing the requirement of this divalent cation for secretion. These data thus suggest that a G-protein is involved in stimulus-response coupling in this model system.

\section{Materials and Methods}

Reagents. GTP (guanosine 5'-triphosphate), GDP (guanosine 5'-diphosphate), GMP (guanosine 5'-monophosphate), GDP[ $\beta$-S] (guanosine-5'[2-thio]diphosphate), Gpp[NH]p (5'-guanylylimidodiphosphate), fMet-Leu-Phe ( $N$-formylmethionylleucylphenylalanine), cholera toxin and digitonin were purchased from Sigma Chemical Company, St. Louis, MO. GTP $\gamma-\mathrm{S}]$ (guanosine-5'-O[3-thio]triphosphate) and $\mathrm{Gpp}\left[\mathrm{CH}_{2}\right] \mathrm{p}$ (guanylyl $[\beta, \gamma$-methylene]diphosphate) were obtained from Boehringer Mannheim, Indianapolis, IN. Pertussis toxin was purchased from List Biochemicals, Campbell, CA. All other materials were reagent grade.

Preparation of cell suspensions. Heparinized (10 units $/ \mathrm{ml}$ ) venous blood was obtained from healthy adult donors. Purified preparations of neutrophils were isolated from this blood by means of $\mathrm{Hy}$ paque/Ficoll gradients [21] followed by standard techniques of dextran sedimentation and hypotonic lysis of erythrocytes [22]. This allowed stud- ies of cell suspensions containing $98 \pm 2 \%$ neutrophils with few contaminating platelets or erythrocytes. The cells were washed and finally suspended in a buffer consisting of $138 \mathrm{mM}$ $\mathrm{NaCl} / 2.7 \mathrm{mM} \mathrm{KCl} / 8.1 \mathrm{mM} \mathrm{Na}{ }_{2} \mathrm{HPO}_{4} / 1.5 \mathrm{mM}$ $\mathrm{KH}_{2} \mathrm{PO}_{4} / 1 \mathrm{mM} \mathrm{CaCl} 2 /$ and $0.6 \mathrm{mM} \mathrm{MgCl} 2(\mathrm{pH}$ 7.4) (buffer $\mathrm{P}$ ). For permeabilization studies, the cells were instead washed once and resuspended in buffer $\mathrm{K}(100 \mathrm{mM} \mathrm{KCl} / 20 \mathrm{mM} \mathrm{NaCl} / 1 \mathrm{mM}$ EGTA/and $30 \mathrm{mM}$ Hepes (pH 7.0).

Neutrophil permeabilization. Permeabilization was performed as previously described [20]. In essence, stock solutions of digitonin $(1 \mathrm{mg} / \mathrm{ml}$ in buffer K) were prepared daily. Neutrophils (25. $10^{6} / \mathrm{ml}$ ) suspended in buffer $\mathrm{K}$ were preincubated for $10 \mathrm{~min}$ at $37^{\circ} \mathrm{C}$. Incubation was at $37^{\circ} \mathrm{C}$ for $25 \mathrm{~min}$ with $10 \mu \mathrm{g} / \mathrm{ml}$ digitonin; the cell suspension was mixed every 5 min.

Lysosomal enzyme release. Following permeabilization, neutrophils were used without washing. They were suspended in buffer $\mathrm{K}$ at a concentration of $5 \cdot 10^{6} / \mathrm{ml}$ with the desired concentration of free $\mathrm{Ca}^{2+}$, which was determined for the buffer using a $\mathrm{Ca}^{2+}$ electrode. The cells were then incubated at $37^{\circ} \mathrm{C}$ for $10 \mathrm{~min}$; cells incubated without calcium and unpermeabilized neutrophils were employed as routine controls. The cell suspensions were then centrifuged at $750 \times g$ for 10 $\min$. Aliquots of the supernatants were taken for standard determinations of $\beta$-glucuronidase (Ref. 23 , an enzyme found exclusively in azurophil granules), lysozyme (Ref. 24; an enzyme found in both specific and azurophil granules), vitamin B-12 binding protein (Ref. 25; a component of specific granules alone) and lactate dehydrogenase activities (Ref. 26; a cytosolic enzyme).

\section{Results}

The release of granule constituents from human neutrophils permeabilized with digitonin is shown in Fig. 1. It can be seen that increasing concentrations of $\mathrm{Ca}^{2+}$ produced a decrease in lactate dehydrogenase release, due to partial resealing of the cells [27]. $\mathrm{Ca}^{2+}$ also induced the secretion of the granule constituents lysozyme, $\beta$-glucuronidase, and vitamin $\mathrm{B}-12$ binding protein. The greatest amount of release was obtained for vitamin B-12 binding protein; this response also required the 

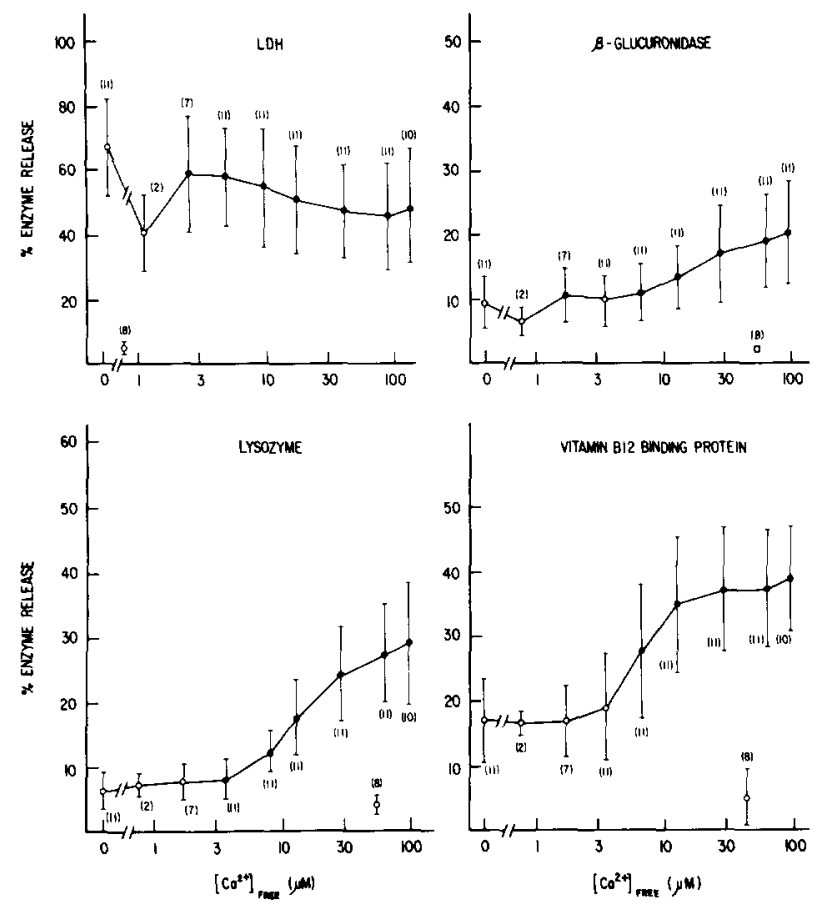

LOH Release
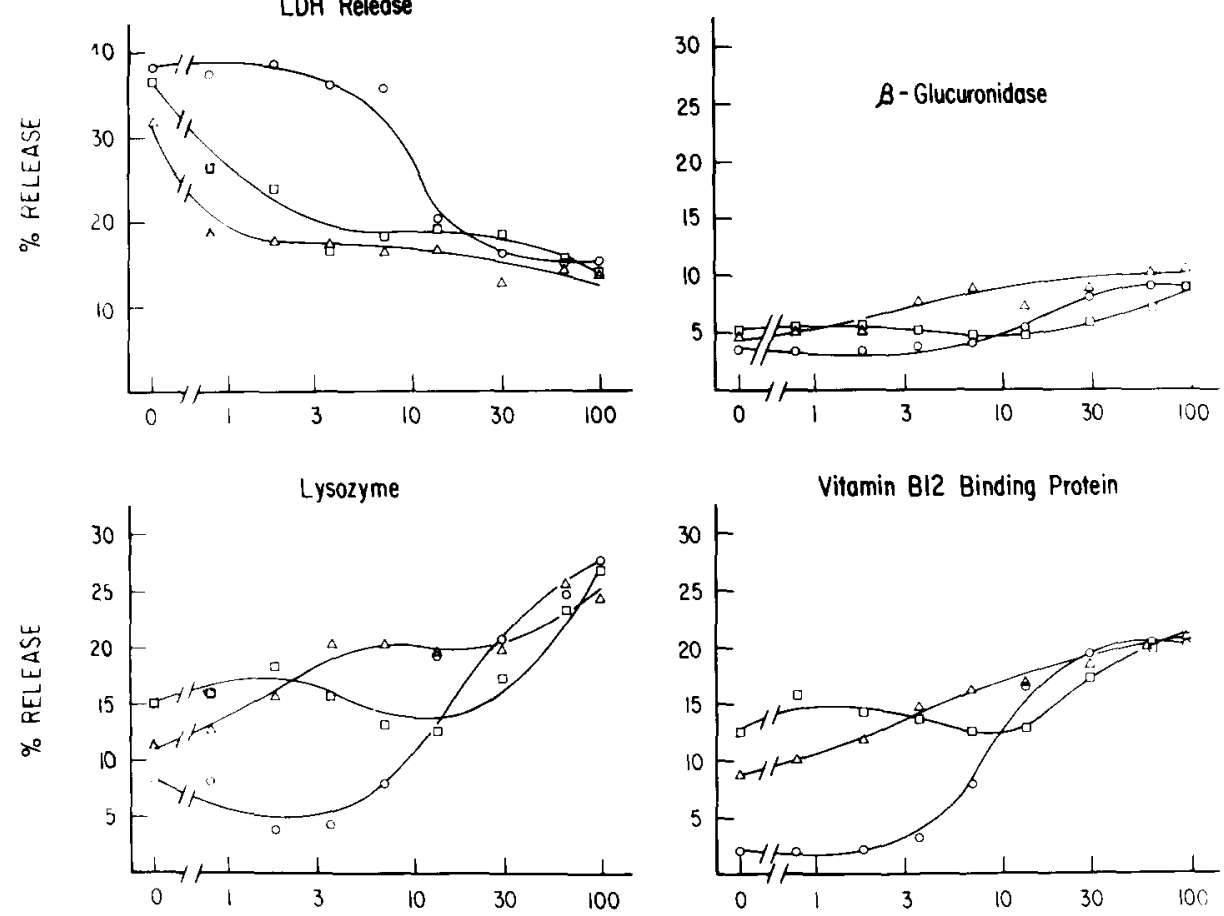

$\left[\mathrm{CO}^{2+}\right]_{\text {FREE }}(\mu \mathrm{M})$

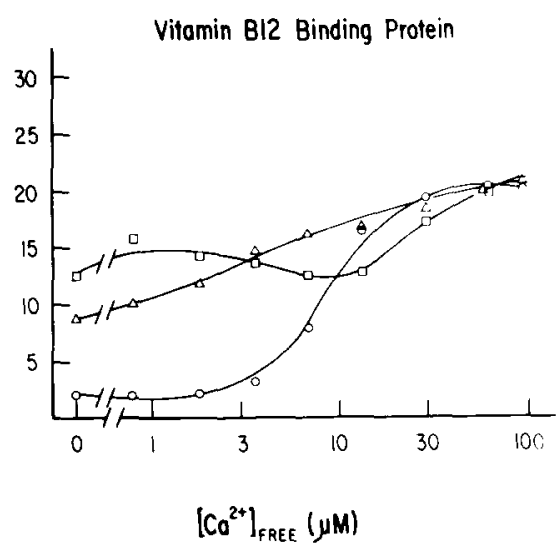

Fig. 1. Secretion of cellular constituents in response to elevated free $\mathrm{Ca}^{2+}$ concentrations. Human neutrophils were permeabilized with digitonin and stimulated to release cellular constituents with $\mathrm{Ca}^{2+}$. The data show release of four constituents and are expressed as the means \pm S.D., with the number of experiments given in parentheses. Solid symbols denote points which were significantly different from control samples (i.e., $\left[\mathrm{Ca}^{2+}\right]_{\text {free }}$ less than $10^{-8} \mathrm{M}$, designated ' 0 ' $\mathrm{Ca}^{2+}$ ) as determined by a Student's paired $t$-test. The single unconnected points represent background release in the absence of permeabilization.

lowest threshold $\mathrm{Ca}^{2+}$ concentration. In contrast, release of $\beta$-glucuronidase was the least responsive to $\mathrm{Ca}^{2+}$. It should be noted that the extent of permeabilization varied substantially from one experiment to the next. This is an intrinsic, unavoidable aspect of permeabilization with cholesterol-complexing agents $[19,20]$ and is reflected in Fig. 1 and the succeeding figures.

Modulation of these responses could be obtained with GTP and Gpp[NH]p (Fig. 2). At

Fig. 2. Effect of GTP and Gpp[NH]p on release of cellular constituents induced by $\mathrm{Ca}^{2+}$. Permeabilized neutrophils were exposed to the indicated concentrations of $\mathrm{Ca}^{2+}$ alone (control) $\mathrm{O}-\mathrm{O}$, with $0.2 \mathrm{mM} \mathrm{GTP} \square-\square$, or with $0.1 \mathrm{mM} \mathrm{Gpp}[\mathrm{NH}] \mathrm{p}$ $\Delta \longrightarrow \triangle$. The results are taken from a single representative experiment, of which at least 3 were performed. 

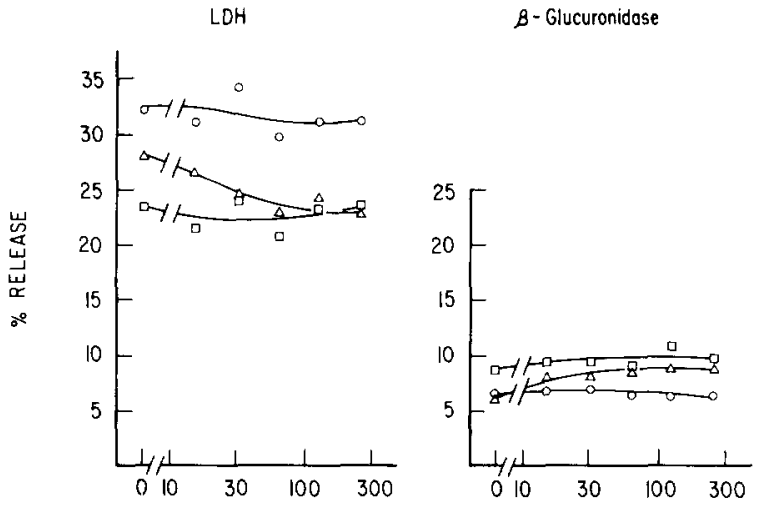

Lysozyme

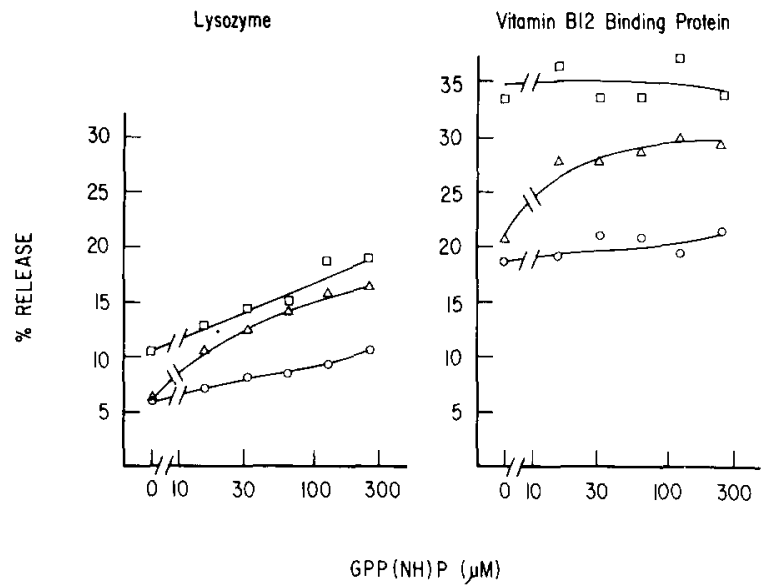

Fig. 3. Effect of Gipp[NH]p on release of cellular constituents induced by three concentrations of $\mathrm{Ca}^{2}$. Permeabilized human neutrophils were exposed to the indicated concentrations of $\left(\mathrm{Gpp}[\mathrm{NH}] \mathrm{p}\right.$ and either zero $\left(0^{\circ}\right.$ less than $\left.10^{-8} \mathrm{M}\right)$ $O \longrightarrow$, low $(3.6 \mu \mathrm{M}) \triangle \longrightarrow$ or high $(100 \mu \mathrm{M})$ $\square-\square$ concentrations of $\mathrm{Ca}^{2}$. The results are taken from a single representative experiment of which at least three were performed.

LDH

B-GLUCURONIDASE
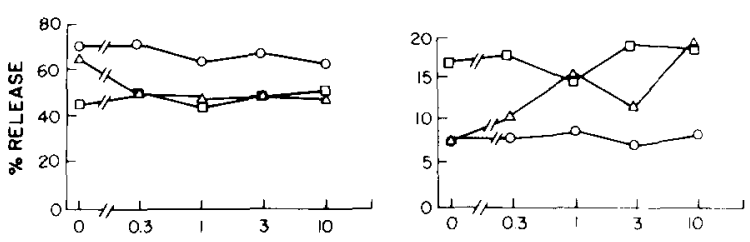

LYSOZYME

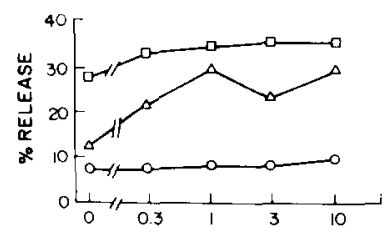

VITAMIN $B_{12}$

BINOING PROTEIN

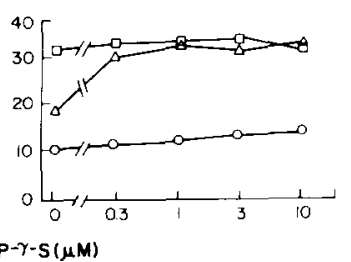

LST

8. Glucurcingse
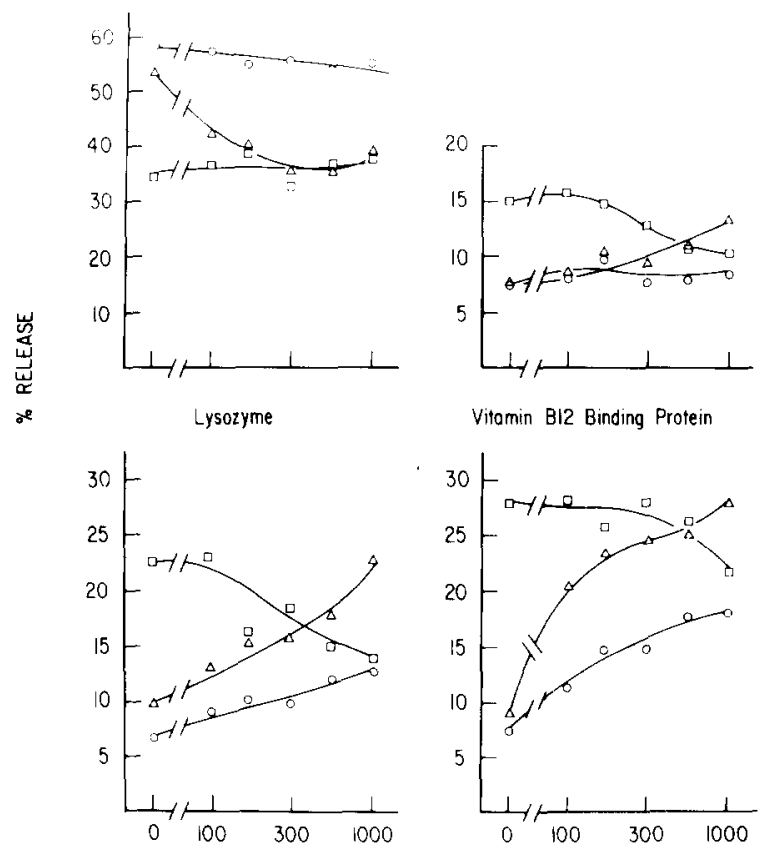

Vitomin Bl2 Binding Protein

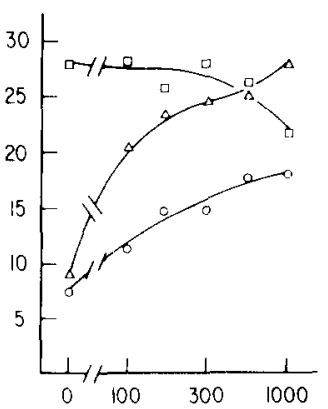

[GTP $\mid(\mu \mathrm{M})$

Fig. 5. Effect of GTP on release of cellular constituents induced by three concentrations of $\mathrm{Ca}^{2}$. Permeabilized human neutrophils were exposed to the indicated concentrations of GTP and either zero (" 0 ' less than $\left.10^{8} \mathrm{M}\right) \mathrm{O}-\ldots \mathrm{O}$, low $(3.6$ $\mu \mathrm{M}) \Delta-\Delta$ or high $(100 \mu \mathrm{M}) \square-\square$ concentrations of $\mathrm{Ca}^{2+}$. The results are taken from a single representative experiment of which at least three were performed.

negligible ('0') $\mathrm{Ca}^{2}$ ' levels, both of these guanine nucleotides induced secretion by themselves. In the presence of $\mathrm{Gpp}[\mathrm{NH}] \mathrm{p}$, additional secretion was obtained for all three granules constituents at low $\mathrm{Ca}^{2+}$ concentrations. Similar results were obtained with GTP[ $\gamma-\mathrm{S}]$ (not shown). Enhanced secretion at low $\mathrm{Ca}^{2+}$ concentrations was not always apparent with GTP, which of ten produced a broad shoulder in this region of the curve. At

Fig. 4. Effect of GTP $\gamma-\mathrm{S}]$ on release of cellular constituents induced by three concentrations of $\mathrm{Ca}^{2}$. Permeabilized human ncutrophils were exposed to the indicated concentrations of GTP $\gamma$-S] and either zero ( 0 ' less than $\left.10^{8} \mathrm{M}\right) \mathrm{O}-\mathrm{O}$. low $(3.6 \mu \mathrm{M}) \Delta-\Delta$ or high $(100 \mu \mathrm{M}) \square-\square$ concentrations of $\mathrm{Ca}^{2}$. The results are taken from a single representative experiment of which at least three were performed. 


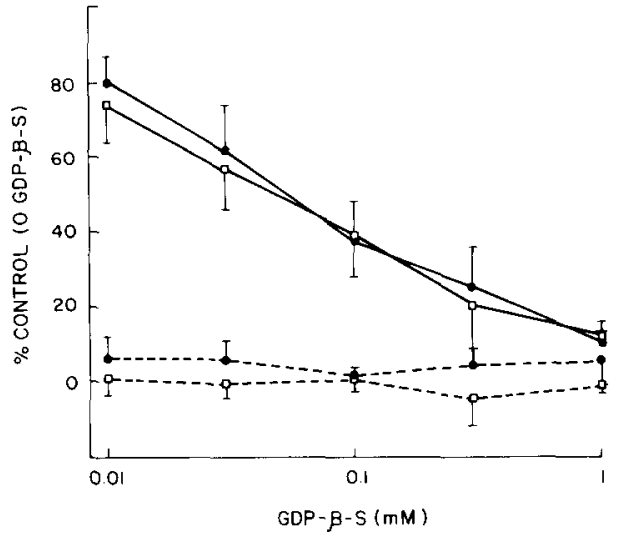

Fig. 6. Blocking of the effects of Gpp[NH]p with GDP $\beta$-S]. Permeabilized human neutrophils were incubated with low concentrations $(3.6 \mu \mathrm{M})$ of $\mathrm{Ca}^{2+}$ and the indicated concentrations of GDP $[\beta-\mathrm{S}]$. In half of the samples, Gpp $[\mathrm{NH}] \mathrm{p}(100$ $\mu \mathrm{M})$ was also present, providing synergy with the $\mathrm{Ca}^{2+}$. Following incubation for $10 \mathrm{~min}$ at $37^{\circ} \mathrm{C}$, the supernatants were assayed for contents of lysozyme ( $\square$ ) and vitamin B-12 binding protein ( $)$. The results are presented as the percentage of control values which were obtained in the absence of GDP $\beta-S]$ (100\% in the presence (solid lines) and $0 \%$ in the absence (broken lines) of Gpp[NH]p) and are given as the means $( \pm$ S.D.) of three experiments.

high $\mathrm{Ca}^{2+}$ concentrations, GTP was often inhibitory (vide infra).

The effects of these guanine nucleotides were dose dependent. As shown in Fig. 3, increasing concentrations of $\mathrm{Gpp}[\mathrm{NH}] \mathrm{p}$ often produced enhanced release of granule constituents at negligible (' 0 ') $\mathrm{Ca}^{2+}$ concentrations (most apparent for lysozyme in the experiment shown). At low (3.6 $\mu \mathrm{M})$ concentrations of $\mathrm{Ca}^{2+}, \mathrm{Gpp}[\mathrm{NH}] \mathrm{p}$ produced a dose-dependent enhancement of release, thereby displaying the synergy shown in Fig. 2. At high $(100 \mu \mathrm{M})$ concentrations of $\mathrm{Ca}^{2+}$, this guanine nucleotide had no effect. Similar results were obtained for GTP $\gamma$-S], which was approx. 10-times more potent (Fig. 4). The presence of fMet-LeuPhe $\left(10^{-7} \mathrm{M}\right), \operatorname{MgATP}(1 \mathrm{mM})$, cyclic AMP (50 $\mu \mathrm{M})$, 2-deoxyglucose $(5 \mathrm{mM})$ or cytochalasin $\mathrm{B}(5$ $\mu \mathrm{g} / \mathrm{ml}$ ) did not affect these dose-response curves (not shown). As stated in Materials and Methods, the permeabilized neutrophils were used without washing; if the cells were washed, $3 \mathrm{mM} \mathrm{MgATP}$ was required for the guanine nucleotides to be effective.

Like Gpp[NH]p and GTP[ $\gamma-\mathrm{S}]$, GTP was a
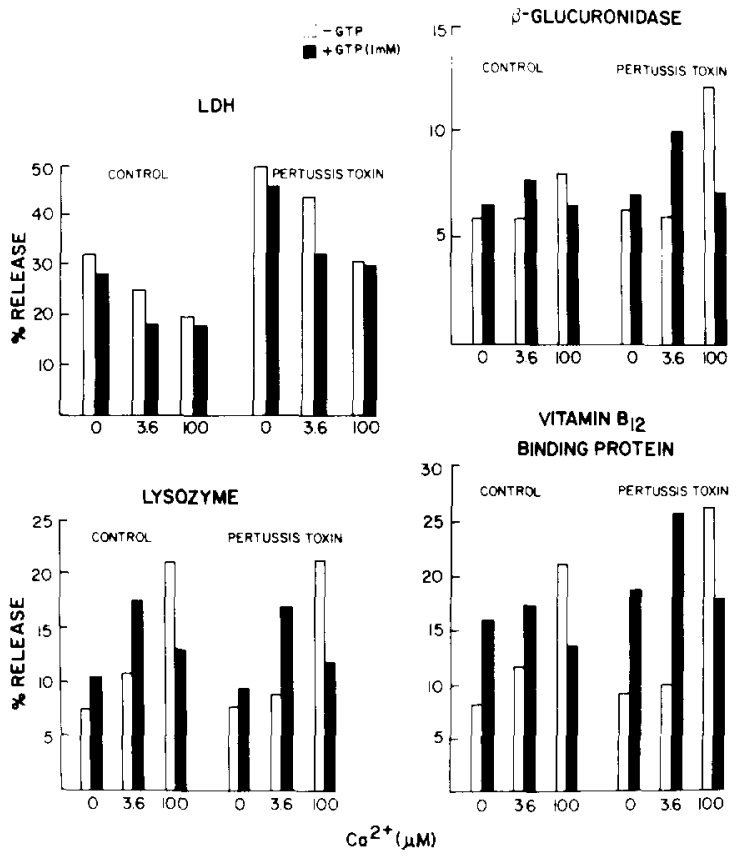

Fig. 7. Effect of pretreatment with pertussis toxin on the synergy between GTP and $\mathrm{Ca}^{2+}$. Human neutrophils were pretreated with or without $1 \mu \mathrm{g} / \mathrm{ml}$ pertussis toxin for $2 \mathrm{~h}$ at $37^{\circ}$ in buffer $P$. The cells were then washed and resuspended in buffer $\mathrm{K}$, after which permeabilization was performed. The permeabilized cells were then exposed to the indicated concentrations of $\mathrm{Ca}^{2+}$ in the presence ( $\square$ ) or absence ( $\square$ ) of GTP. The results shown are from a single representative experiment of which at least three were performed.

secretagogue in its own right and also enhanced release at low $\mathrm{Ca}^{2+}$ concentrations (Fig. 5). However, at high concentrations of both GTP and $\mathrm{Ca}^{2+}$, profound inhibition of secretion was observed. Some inhibition under similar conditions was found with $\mathrm{Gpp}\left[\mathrm{CH}_{2}\right]$, which did not stimulate secretion at low $\mathrm{Ca}^{2+}$ concentrations (not shown). Furthermore, over the same range of guanine nucleotide concentrations, no effects were found for GMP, GDP or GDP $\beta$-S] (not shown). However, GDP $\beta$-S] effectively blocked the effects of $\mathrm{Gpp}[\mathrm{NH}] \mathrm{p}$ (Fig. 6).

As reported by others, treatment of intact neutrophils with pertussis toxin produced a virtually complete blockage of receptor mediated responses. We found that a $2-\mathrm{h}$ incubation with $1 \mu \mathrm{g} / \mathrm{ml}$ of pertussis toxin in buffer $P$ inhibited fMet-Leu-Phe stimulated, cytochalasin B-enhanced degranulation by $89 \pm 11 \%(n=8)$. These pertussis toxin pretreated cells were then permeabilized with dig- 
itonin and exposed to GTP at different $\mathrm{Ca}^{2+}$ concentrations. As shown in Fig. 7, this pretreatment did not block the synergistic effects of GTP and $\mathrm{Ca}^{2+}$ on secretion. Similar results were obtained with Gpp[NH]p and with cholera toxin (not shown). Attempts to treat permeabilized neutrophils with activated pertussis toxin resulted in irreversible aggregation of the cells (L.A. Sklar, personal communication).

\section{Discussion}

In this work, we found that permeabilized human neutrophils secreted lysosomal constituents when exposed to micromolar levels of $\mathrm{Ca}^{2+}$ or to certain guanine nucleotides. Furthermore, these two agents acted in a synergistic manner. Finally, we found that this synergism was not blocked by exposure to pertussis toxin. Secretion induced by $\mathrm{Ca}^{2+}$ in permeabilized cells has been reported by a number of laboratories, including our own [19,20,28-36]. The amount of $\mathrm{Ca}^{2+}$ required to stimulate this response, while comparable to that observed for some other permeabilized systems, is still one order of magnitude higher than that which has been indicated to exist in stimulated neutrophils on the basis of studies with quin2 [7-11]. Several factors may account for this: (1) In our studies, free $\mathrm{Ca}^{2+}$ concentrations were measured, not calculated. In view of the association constants employed by some other laboratories [37-40], our free $\mathrm{Ca}^{2+}$ concentrations are likely to appear overestimated in this regard. (2) Quin2 is known to blunt the very intracellular $\mathrm{Ca}^{2+}$ response which it measures, thereby underestimating the peak levels observed [41-43]. (3) Quin2 also measures overall, rather than localized, $\mathrm{Ca}^{2+}$ concentrations. It may be that the concentrations of $\mathrm{Ca}^{2+}$ in local, strategic areas of the intracellular space are of the greatest importance [43]. Nonetheless, it is possible that the secretion induced by $\mathrm{Ca}^{2+}$ alone in permeabilized neutrophils is nonphysiologic, perhaps being mediated by a primitive, vestigial system.

However, the fact that GTP and some of its analogues potentiate $\mathrm{Ca}^{2+}$-induced secretion and reduce the $\mathrm{Ca}^{2+}$ requirement by one-third to one order of magnitude suggests that the permeabilized neutrophil may be a more accurate model of physiologic events than otherwise indicated. GTP has also been reported to reduce $\mathrm{Ca}^{2+}$ requirements in other permeabilized cell systems $[44,45]$, including neutrophils [34]. That GTP $\gamma-\mathrm{S}]$ is a secretagogue in its own right has also been reported for patch-pipetted mast cells [46]. This effect in permeabilized neutrophils is not due to $\mathrm{Ca}^{2+}$ contamination of the GTP nor due to residual $\mathrm{Ca}^{2+}$ contributed by the cells, since the same stimulation was seen after washing the neutrophils (not shown). This stimulation by GTP alone could be relevant to stimulus-response coupling if high concentrations of this guanine nucleotide were achieved locally in the cytosol. Inhibition at high concentrations of both $\mathrm{Ca}^{2+}$ and GTP might also be relevant under localized conditions.

Synergy between $\mathrm{Ca}^{2+}$ and classic secretagogues has been reported for a number of permeabilized cells. For example, thrombin and diacylglycerol are synergistic with $\mathrm{Ca}^{2+}$ and GTP in permeabilized platelets $[32,45,47]$. Synergy has also been reported with phorbol esters in adrenal medullary cells [48] and pancreatic acinar cells [33] and with cyclic nucleotides in platelets [31]. However, we found no such potentiation when fMet-Leu-Phe or phorbol myristate acetate (PMA) were presented to permeabilized neutrophils, even in the presence of $\mathrm{Gpp}[\mathrm{NH}] \mathrm{p}$. Barrowman et al [34] found that PMA actually inhibited $\mathrm{Ca}^{2+}{ }^{2+}$ duced secretion in neutrophils permeabilized with Sendai virus [34].

There are some differences in detail between this work and that of Barrowman et al. [34]. The first major difference is that in our studies, only GTP proved to be a consistent secretagogue in the absence of $\mathrm{Ca}^{2+}$; the other group found stimulation in the rank order of GTP- $[\gamma-\mathrm{S}]>\mathrm{Gpp}[\mathrm{NH}] \mathrm{p}$ $>$ GTP. Secondly, they found that GDP $\beta-S]$ inhibited $\mathrm{Ca}^{2+}$-stimulated degranulation, while we did not. These discrepancies might be attributable to two major differences in methodology: species and permeabilization system. Barrowman et al. [34] employed rabbit neutrophils, while we used human cells. Many of the details of secretion differ between these species. The means of permeabilization might also be a factor. This might be expected, since the two techniques are vastly different in mechanism of action and, indeed, produce different pore sizes (treatment with digitonin 
permits the release of lactate dehydrogenase, while treatment with Sendai virus does not). Thus, those coupling systems which promote the action of guanine nucleotides in the absence of $\mathrm{Ca}^{2+}$ and permit GDP $[\beta-\mathrm{S}]$ to interfere with $\mathrm{Ca}^{2+}$-induced secretion appear to remain intact in Barrowman's system.

The effects of GTP and its stimulatory analogues are likely to be mediated by a G-protein, a conclusion also reached by Barrowman et al. [34]. The rank order of potency for enhancing $\mathrm{Ca}^{2+}$-induced secretion, namely GTP $<$ Gpp $[N H] p<$ GTP $[\gamma-\mathrm{S}]$, as well as the concentrations employed, strongly suggest that these guanine nucleotides are acting specifically with a G-protein. The failure of GMP, GDP, and GDP $\beta$-S] to elicit any comparable effects and the ability of this latter nucleotide to block Gpp[NH]P (Fig. 6) support this conclusion. However, it is unlikely that these guanine nucleotides are operating through the same pool of $\mathrm{N}_{i}$ as the fMet-Leu-Phe-triggered responses, since treatment with pertussis toxin blocked the effects of the peptide without interfering with those of $\mathrm{Ca}^{2+}$ (Ref. 34 and this work). It could be argued that pertussis toxin might simply uncouple the $\mathrm{N}_{\mathrm{i}}$-like protein from the fMet-Leu-Phe receptor, leaving subsequent interactions of the G-protein intact. This model is not likely since the receptor and the $\mathrm{N}_{\mathrm{i}}$-like protein are fully coupled in the permeabilized neutrophil [36] yet fMet-LeuPhe has no effect upon $\mathrm{Ca}^{2+}$-induced secretion (Ref. 20 and this work). It is more likely that the guanine nucleotides are using a different G-protein than $\mathrm{N}_{\mathrm{i}}$. Alternatively, there is the possibility that there is a pool of $\mathrm{N}_{\mathrm{i}}$ which is inaccessible to the toxin under the conditions employed; this possibility could not be tested since the permeabilized cells did not tolerate conditions necessary to inactivate all of the $N_{i}$.

The fact that guanine nucleotides diminished release of lactate dehydrogenase deserves some comment. The decreased release of this cytosolic enzyme following exposure to $\mathrm{Ca}^{2+}$ has been shown to be the result of resealing of the cells with respect to large-molecular-weight solutes, with access by small solutes remaining unimpaired [20]. This may well be due to the fact that degranulation results in the cell surface incorporation of granule membranes [49], which are known to be resistant to permeabilization by digitonin $[20,50]$. Thus, one would expect that a decrease in lactate dehydrogenase release should be a direct accompaniment of degranulation and that any synergy between $\mathrm{Ca}^{2+}$ and guanine nucleotides would be expressed in both responses. Indeed, lactate dehydrogenase release might be a more sensitive (although indirect) indicator of degranulation since the more labile tertiary granules (whose contents were not measured in these studies) might fuse with the plasma membrane under milder conditions than either azurophil or specific granules. While difficult to rule out entirely, any 'general membrane effect' of the guanine nucleotides is unlikely in view of the fact that these agents do not substantially affect the kinetics of degranulation, as monitored continuously by elastase release and right angle light scatter [35]. Full access of EG'TA to the intracellular space, as indicated by its ability to stop $\mathrm{Ca}^{2+}$-induced degranulation within $5 \mathrm{~s}$, was not impaired by guanine nucleotides [35]. Finally, access of guanine nucleotides to G-proteins coupled to the fMet-Leu-Phe receptors was complete under all conditions [36].

In summary, then, we have found that GTP and some of its analogues are both stimulatory in the absence of $\mathrm{Ca}^{2+}$ and also synergistic with $\mathrm{Ca}^{2+}$ in inducing degranulation. These results suggest that the permeabilized neutrophil system may be accurately modeling the cytoplasmic events taking place during granule discharge. While the data are strongly suggestive, the issue of whether or not this system is the one actually operating in intact cells remains to be resolved. The data also suggest the involvement of as yet unidentified G-proteins in this stimulus-response coupling pathway. It is likely that other modulators of this pathway remain to be discovered.

\section{Acknowledgements}

This work was supported by NIH grant AM 32471. J.E.S. is a Senior Fellow of the Arthritis Foundation.

\section{References}

1 Smolen, J.E., Korchak, H.M. and Weissmann, G. (1981) Biochim. Biophys. Acta 677, 512-520 
2 Simchowitz, L. and Spilberg, I. (1979) J. Lab. Clin. Med. 93, 583-593

3 Naccache, P.H., Showell, H.J., Becker, E.L. and Sha'afi, R.I. (1979) J. Cell Biol. 83. 179-186

4 Naccache, P.H., Volpi, M., Showell, H.J., Becker, E.L. and Sha'afi, R.I. (1979) Science 203, 461-463

5 Smolen, J.E and Wcissmann. G. (1982) Biochim. Biophys. Acta $720,172-180$

6 Smolen, J.E., Eisenstat, B.A. and Weissmann, G. (1982) Biochim. Biophys. Acta 717, 422-431

7 White, J.R., Naccache, P.H., Molski, T.F.P., Borgeat, P. and Sha'afi, R.I. (1983) Biochem. Biophys. Res. Commun. $113,44-50$

8 Pozzan, T., Lew, D.P., Wollheim, C.B. and Tsein, R.Y. (1983) Science 221, 1413-1415

9 Korchak. H.M., Rutherford, L.E. and Weissmann, G. (1984) J. Biol. Chem. 259, 4070-4075

10 Korchak, H.M., Vienne, K., Rutherford, L.E., Wilkenfeld, C., Finkelstein, M.C. and Weissmann, G. (1984) J. Biol. Chem. 259, 4076-4082

11 Naccache, P.H., Molski, T.F.P., Borgeat, P. and Sha'afi, R.I. (1985) J. Cell. Physiol. 122, 273-280

12 Molski, T.F.P., Naccache, P.H., Marsh, M.L., Kermode, J., Becker, E.L. and Sha'afi, R.I. (1984) Biochem. Biophys. Res. Commun. 124, 644-650

13 Lad, P.M., Olson, C.V. and Smiley, P.A. (1985) Proc. Natl Acad. Sci. USA 82, 869-873

14 Bradford, P.G. and Rubin, R.P. (1985) FEBS Lett. 183, $317-320$

15 Shefcyk, J., Yassin, R., Volpi, M., Molski, T.F.P., Naccache, P.H., Munoz, J.J.. Becker, E.L.. Feinstein, M.B. and Sha'afi, R.I. (1985) Biochem. Biophys. Res. Commun. 126, 1174-1181

16 Becker, E.L., Kermode, J.C., Naccache, P.H., Yassin, R., Marsh, M.L., Munoz, J.J. and Sha'afi, R.I. (1985) J. Cell Biol. 100, 1641-1646

17 Volpi, M., Naccache, P.H., Molski, T.F.P., Shefcyk, J., Huang, C.K., Marsh, M.L., Munoz, J.. Becker, E.L. and Sha'afi, R.I. (1985) Proc. Nati. Acad. Sci. USA 82 , $2708-2712$

18 Snyderman, R., Pike, M.C., Edge, S. and Lane, B. (1984) J. Biol. Chem. 98, 444-448

19 Smolen, J.E. and Stoehr, S.J. (1985) J. Immunol. 134 , $1859-1865$

20) Smolen, J.E. Stoehr, S.J. and Boxer, L.A. (1986) Biochim. Biophys. Acta 886, 1-17

21 Boyum, A. (1968) Scand. J. Clin. Lab. Invest. 21, 77-89

22 Zurier, R.B., Hoffstein, S. and Weissmann, G. (1973) Proc. Natl. Acad. Sci. USA 70, 844-848

23 Brittinger, G.R., Hirschhorn, R., Douglas, S.D. and Weissmann, G. (1968) J. Cell Biol. 37, 394-411

24 (1972) Worthington Enzyme Manual, pp. 100-101 Worthington Biochem. Co., Freehold
25 Smith, G.P. and Peters, T.J. (1982) Biochim. Biophys. Acta 719. 304-308

26 Wacker, W.E.C., Ulmer, D.D. and Vallee, B.L. (1956) N. Eng. J. Med. 255, 449-456

27 Smolen, J.E., Stochr, S.J. and Boxer. L.A. (1984) J. Cell Biol. 99, 331a (abstract)

28 Bennett, J.P., Cockroft, S. and Gomperts, B.D. (1981) J. Physiol. 317, 335-345

29 Dunn. L.A. and Holz. R.W. (1983) J. Biol. Chem. 258. 4989-4993

30 Wilson, S.P. and Kirshner, N. (1983) J. Biol. Chem. 258. 4994-5000

31 Knight, D.E. and Scrutton, M.C. (1984) Nature 309, 66-68

32 Haslam, R.J. and Davidson. M.M.L. (1984) Biochem. J. $222,351-361$

33 Knight. D.E. and Koh, E. (1984) Cell Calcium 5, 401-418

34 Barrowman. M.M., Cockroft, S. and Gomperts, B.D. (1986) Nature 319, 504-507

35 Smolen, J.E., Stoehr, S.J. Traynor, A.E. and Sklar. L.A. J. Leuk. Bid. in the press

36 Sklar, L.A., Bokoch, G.M., Button, D. and Smolen, J.E. J. Biol. Chem. in the press

37 Porzig, H. and Stoffel, D. (1978) J. Memb. Biol. 40, 117-142

38 Knight, D.E., Hallam, T.J. and Scrutton, M.C. (1982) Nature 296, 256-257

39 Burgess, G.M., McKinney, J.S., Fabiato, A., Leslie, B.A. and Putney, J.W., Jr. (1983) J. Biol. Chem. 258, 15336-15345

40 Lapetina, E.G., Watson. S.P. and Cuatrecasas, P. (1984) Proc. Natl. Acad. Sci. U.S.A. 81, 7431-7435

41 Lew, P.D., Wollheim, C.B., Waldvogel, F.A. and Pozzan. T. (1984) J. Cell Biol. 99, 1212-1220

42 Stickle, D.F., Daniele, R.P. and Holian, A. (1984) J. Cell. Physiol. 121, 458-466

43 Johnson, P.C., Ware, J.A., Cliveden, P.B., Smith, M. Dvorak, A.M. and Salzman, E.W. (1985) J. Biol. Chem. 260, 2069-2076

44 Haslam, R.J. and Davidson, M.M.L. (1984) FEBS Lett. $174,90-95$

45 Haslam, R.J. and Davidson, M.M.L. (1984) J. Recept. Res. 4. $605-629$

46 Fernandez, J.M.. Neher, E. and Gomperts, B.D. (1984) Nature $312,1-3$

47 Aktories, K. and Jakobs, K.H. (1984) Eur. J. Biochem. 145. $333-338$

48 Knight, D.E. and Baker, P.F. (1983) FEBS Lett. 160, $98-100$

49 Smolen, J.E. Todd III, R.F. and Boxer, L.A. (1986) Am. J. Pathol. 124, 281-285

50 Styrt, B., Johnson, P.C. and Klempner, M.S. (1985) Tissue and Cell 17. 793-800 